\title{
STRATEGI AKOMODASI KOMUNIKASI DALAM PROSES PEMBELAJARAN BAHASA INDONESIA
}

\author{
Communication Accommodation Strategy in Indonesian Language Learning Process
}

\author{
Reza Amarta Prayoga ${ }^{1}$ dan Dian Palupi ${ }^{2}$ \\ ${ }^{1,2}$ Pusat Pengembangan dan Pelindungan Bahasa dan Sastra \\ ${ }^{1}$ reza.amarta@kemdikbud.go.id, ${ }^{2}$ dian.palupi@kemdikbud.go.id
} Naskah Diterima Tanggal 2 Februari 2020 - Direvisi Akhir Tanggal 24 Oktober 2020-Disetujui Tanggal 28 November 2020
doi: https://doi.org/10.26499/rnh.v9i2.2525

\begin{abstract}
Kemampuan guru dan siswa dalam kegiatan pembelajaran sangat dipengaruhi oleh komunikasi antarkeduanya. Untuk menjalin komunikasi yang interaktif antarkeduanya dalam upaya mencapai tujuan pembelajaran, penyesuaian atau adaptasi (akomodasi) bahasa dilakukan. Tujuannya ialah terjadinya pembelajaran yang timbal balik. Ada strategi-strategi yang dilakukan oleh guru-siswa, baik secara sadar maupun tidak sadar, untuk melakukan adaptasi (akomodasi) bahasa dalam kegiatan pembelajaran. Penulisan artikel ini bertujuan untuk (a) mendeksripsikan dominasi penggunaan strategi akomodasi komunikasi dalam pembelajaran di kelas dan (b) mendeskripsikan alasan atau faktor yang memengaruhi penggunaan strategi akomodasi komunikasi antara guru dan siswa dalam pembelajaran di kelas. Sumber data penelitian ini berupa guru dan siswa dalam kegiatan pembelajaran bahasa Indonesia di kelas pada tiga SMA di Jakarta. Data penelitiannya adalah tuturan verbal dan nonverbal dalam dalam kegiatan pembelajaran bahasa Indonesia. Penelitian ini menggunakan metode kualitatif deskriptif yang mengandalkan data berupa hasil wawancara, catatan observasi, dan rekaman audiovisual kegiatan pembelajaran bahasa Indonesia di tiga SMA di Jakarta. Hasil penelitian menunjukkan bahwa tiga strategi, yaitu pengelolaan wacana, emotional ekspresi, dan interpretabilitas mendominasi penggunaan strategi akomodasi komunikasi yang dilakukan guru dan siswa. Penyederhanaan pesan dan pembangunan kepercayaan diri menjadi alasan atau faktor terjadinya strategi akomodasi komunikasi yang dibangun dalam interaksi bahasa guru dan siswa di kelas.
\end{abstract}

Kata-kata kunci: kelas; pembelajaran bahasa Indonesia; strategi akomodasi komunikasi

\begin{abstract}
The ability of teachers and students in learning activities is greatly influenced by the communication between the two. To establish interactive communication between the two, to achieve learning objectives, language adjustment, or adaptation (accommodation) is carried out so that mutual learning occurs. There are strategies carried out by teacher-students, both consciously and unconsciously, to adapt (accommodation) language in learning activities. Writing this article aims to (a) describe the dominance of the use of communication accommodation strategies in classroom learning and (b) describe the reasons or factors that influence the use of communication accommodation strategies between teachers and students in classroom learning. The data sources of this research are teachers and students in Indonesian language learning activities in classes in three high schools in Jakarta. The research data is verbal and nonverbal speech in Indonesian language learning activities. This research method uses descriptive qualitative which relies on data in the form of interviews, observation notes, and audiovisual recordings of Indonesian language learning activities in three high schools in Jakarta. The results showed that three strategies, namely the management of discourse, emotional expression, and interpretability dominate the use of communication accommodation strategies by teachers and students. Simplifying messages and building self-confidence are the reasons or factors for the occurrence of communication accommodation strategies that are built in the language interactions of teachers and students in the classroom.
\end{abstract}

Key words: class; Indonesian language learning; communication accommodation strategies

How to Cite: Prayoga, Reza Amarta dan Dian Palupi. (2020). Strategi Akomodasi Komunikasi dalam Proses Pembelajaran Bahasa Indonesia. Ranah: Jurnal Kajian Bahasa. 9(2). 341-357. doi: https://doi.org/10.26499/rnh.v9i2.2525 


\section{PENDAHULUAN}

Strategi akomodasi komunikasi telah diterapkan dalam bidang pembelajaran sejak lama seperti terlihat dalam penelitian yang dilakukan oleh O'Malley, et al (1985) yang berjudul “Learning Strategy Applications with Students of English as a Second Language”. Penelitian ini melihat pentingnya strategi pembelajaran dalam pemerolehan keterampilan bahasa kedua. Hasil penelitian menunjukkan bahwa siswa menggunakan berbagai strategi pembelajaran, tetapi biasanya menggunakan strategi yang lebih akrab dan menerapkannya pada titik diskret daripada tugas integratif. Strategi akomodasi komunikasi dalam bidang pembelajaran juga telah digunakan oleh Jones, Elizabeth et al, (1999) dalam penelitian yang berjudul "Strategies of Accomodation: Development of a Coding System for Conversational Interaction”. Penelitian ini melihat strategi akomodasi komunikasi dalam konteks akademik, yaitu pada lima puluh interaksi antara dua siswa (latar belakang etnis Australia atau Cina) yang direkam. Hasil penelitian ini menunjukkan bahwa peserta laki-laki lebih banyak menggunakan interpretabilitas (sebagian besar pertanyaan), sedangkan perempuan menggunakan manajemen wacana untuk mengembangkan perspektif bersama. Hasilnya memperjelas bahwa tidak ada korespodensi otomatis antara perilaku dan strategi yang mereka buat.

Penelitian yang dilakukan oleh Mahadhir, Nor, \& Azman, (2014) menelaah strategi akomodasi komunikasi dalam interaksi keluarga multietnis Malaysia (Communication Accomodation Strategies in Malaysian Multiracial Family Interactions). Hasil temuannya menunjukkan beberapa hal. Pertama, strategi aproksimasi, informan pertama (anak perempuan) menggunakan bahasa Melayu dialek utara ketika berbicara kepada ibunya. Ia juga menerapkan budaya Melayu dalam penghormatannya kepada orang tua sebagai bentuk pemertahanan perbedaan status di antara keduanya (anak dan orang tua). Kedua, strategi interpretabilitas, informan pertama (anak perempuan) terlihat akan menggeser fokus koridor antarkelompok dalam pembicaraan ibunya dan bersikap netral agar tidak memicu konflik (meredam perbedaan). Ketiga, strategi pengelolaan wacana, informan pertama (anak perempuan) akan menunjukkan perilaku linguistik yang berbeda saat ia mengganti topik atau isi pembicaan saat informan kedua (ibunya) meremehkan pamannya yang juga multiras. Keempat, secara umum informan pertama dan kedua menggunakan strategi pengendalian diri yang positif sepanjang interaksi mereka. Mereka menyadari posisi mereka sebagai anak dan ibu. Dalam simpulannya, kajian ini menegaskan bahwa meski subjek yang diteliti ini hanya didasarkan pada 1 keluarga yang diambil hanya dengan interaksi ibu dan anak, teori akomodasi komunikasi mampu 
menawarkan kerangka kerja yang berguna dalam menganalisis peran anggota dalam kelompok sosial.

Sementara itu, penelitian strategi komunikasi di Indonesia telah dilakukan oleh Siddik Masrur; Arifin, Syawal (2019), yaitu strategi komunikasi siswa dan guru kelas XI SMAN 2 Sangatta Utara dalam proses pembelajaran Bahasa Indonesia. Hasil penelitian ini berupa strategi: (1) saat berkomunikasi dengan teman sekelas, siswa menggunakan berbagai strategi komunikasi, seperti strategi komunikasi peniruan, penggunaan bahasa tubuh tertentu sesuai dengan makna komunikasi yang ingin dicapainya, dan strategi komunikasi tipe kesadaran transfer dan (2) strategi komunikasi di kelas kebanyakan dilakukan oleh guru saat berkomunikasi dengan siswanya. Strategi komunikasi siswa dengan guru berupa: (a) strategi paraphrase, (b) tipe kesadaran transfer, (c) tipe meminta bantuan, (d) tipe menghindar, dan (e) tipe peniruan.

Gap masalah pada penelitian terdahulu masih belum menyentuh aspek akomodasi komunikasi dalam pembelajaran, tetapi lebih pada proses akomodasi entitas bahasa antaretnis. Penelitian ini berusaha mengisi gap tersebut dengan menambah sudut pandang lain yaitu dengan melihat penggunaan lima strategi akomodasi komunikasi yang dikembangkan oleh Giles (2016) dalam interaksi guru dan siswa saat pembelajaran berlangsung di tiga SMA di Jakarta. Kelima strategi tersebut ialah strategi aproksimasi, interpretabilitas, pengelolaan wacana, pengendalian diri, dan ekspresi emosional. Penelitian ini bertujuan mendeskripsikan penggunaan strategi akomodasi komunikasi dalam interaksi pembelajaran di kelas, dominasi strategi yang digunakan dalam interaksi pembelajaran di kelas, dan faktor yang menyebabkan terjadinya penggunaan kelima strategi tersebut dalam pembelajaran.

Interaksi guru dan siswa dalam kegiatan pembelajaran yang di dalamnya terdapat penyesuaian atau adaptasi bahasa memunculkan ketertarikan penulis untuk mengidentifikasi proses strategi akomodasi komunikasi yang dibangun oleh guru-siswa dan siswa-guru dalam kegiatan pembelajaran di kelas pada jenjang sekolah menengah atas di Jakarta. Kegiatan pembelajaran di kelas yang menjadi fokus kajian ini adalah bahasa Indonesia. Hal itu didasari pada peran bahasa Indonesia yang mencakup seluruh aspek vital kehidupan masyarakat Indonesia yang kultural, termasuk di dalamnya ranah pendidikan. 


\section{LANDASAN TEORI}

Giles (2016:41) menyatakan bahwa ada lima strategi yang dilakukan dalam melakukan akomodasi bahasa, baik dalam bentuk konvergensi (menjadi sama/menyerupai) maupun divergensi (tidak sama/mempertahankan). Pertama, strategi aproksimasi (approximation strategies), strategi yang memfokuskan pada produktivitas bahasa dan komunikasi penutur pada mitra tutur, baik secara verbal maupun nonverbal. Produktivitas bahasa yang dimaksud meliputi aksen, logat, jeda bicara, dan isyarat penutur. Jika penutur melakukan itu dan menyerupai mitra tutur, dapat dikatakan bahwa ia melakukan konvergensi. Jika sebaliknyapenutur tidak ingin menyerupai mitra tutur-ia melakukan divergensi pada strategi tersebut. Kedua, strategi interpretabilitas (interpretability strategies), strategi yang dilakukan penutur atau orang yang melakukan interaksi untuk meyakinkan diri penutur atas pemahaman mitra tutur tentang apa yang dikomunikasikan antar keduanya. Strategi yang dilakukan dapat berupa penyederhanaan kalimat: menggunakan kosa kata yang sederhana dan mampu dipahami oleh mitra tutur. Contohnya ialah guru yang ingin mengetahui pemahaman siswa akan melakukan pengulangan komunikasi tentang pemahaman siswa atas materi yang telah diberikan. Ketiga, strategi pengelolaan wacana (discourse management strategies), strategi ketika penutur fokus pada pembicaraan makro mitra tutur, memiliki kepentingan bersama, seperti isi atau topik percakapan, lalu pengelolaan nonverbal, seperti posisi raut wajah, posisi penutur dan mitra tutur, serta struktur percakapan. Misalnya, guru yang terus menerus bicara, itu artinya guru mendominasi komunikasi. Artinya, guru melakukan divergensi pada strategi tersebut. Banyaknya interaksi yang dibangun dalam pembelajaran, antara guru-siswa melalui pertanyaan dan umpan balik, mencirikan pengelolaan wacana, baik yang bersifat konvergensi maupun divergensi. Keempat, strategi pengendalian diri (interpersonal control strategies), strategi yang memfokuskan diri pada kontrol interpersonal untuk saling mengingatkan tentang posisi penutur dan mitra tuturnya. Misalnya, dalam kegiatan pembelajaran di kelas, kontrol interpersonal tampak pada posisi atau hubungan yang dibangun guru dan siswa. Kelima, strategi ekspresi emosional (emotional expressions), strategi yang fokus pada kebutuhan penutur.

Kecenderungan berkonvergensi atau berdivergensi dalam interaksi bahasa dapat terjadi di setiap aktivitas situasi tutur termasuk di dalam kelas saat kegiatan pembelajaran berlangsung. Dimensi nilai sosial disinyalir dapat melatarbelakangi proses perubahan perilaku berbahasa tersebut. Kedudukan bahasa Indonesia dalam ranah pendidikan, bahasa ibu, status sosial atau identitas sosial, dan hubungan personal di lingkungan sekolah dapat memungkinkan terjadinya akomodasi bahasa, baik mendekatkan (konvergensi) maupun menjauhkan (divergensi). 
Akomodasi adalah teori dalam sosiolinguistik yang bertujuan menjelaskan mengapa orangorang melakukan modifikasi gaya tuturannya menjadi lebih sama (konvergensi) atau kurang sama (divergensi) dengan tuturan lawan wicaranya (Crystal, 2008).

Proses interaksi bahasa antara guru-siswa dan/atau siswa-guru dalam kegiatan pembelajaran di kelas memiliki kerangka yang sama, yaitu tujuan pembelajaran yang hendak dicapai. Dalam proses interaksi pembelajaran tersebut, interaksi bahasa lisan memegang peranan penting. Di sisi lain, pola hubungan interaksi antara guru dan siswa menggunakan bahasa dalam pembelajaran di kelas seharusnya menunjukkan bentuk kesopansantunan (Kholidah, 2015). Menurut Halliday (1985:65), kelas merupakan realitas kehidupan yang di dalamnya terjadi proses komunikasi, saling bertukar pengalaman, mengeskpresikan kesetiakawanan, mengambil putusan, dan membuat perencanaan. Pengaturan bertutur dan kontrol interaksi lisan sangat ditekankan. Hal tersebut disebabkan oleh situasi tutur pembelajaran yang idealnya berlangsung formal. Akan tetapi, pada kenyataannya, seringkali bahasa ragam formal pada situasi tutur ini tidak hadir dalam lingkarannya. Penyesuaian dan adaptasi interaksi tutur, baik dalam bentuk konvergensi maupun divergensi, dalam pembelajaran di kelas bertujuan untuk menegosiasikan hubungan-hubungan antarpersonal (guru dan siswa) sebagai sarana diplomasi guru untuk mencapai tujuan pembelajaran.

\section{METODE PENELITIAN}

Kajian ini dilakukan dengan pendekatan kualitatif deskriptif untuk mengidentifikasi strategi akomodasi komunikasi antara guru dan siswa di dalam kegiatan pembelajaran bahasa Indonesia. Penelitian ini dilakukan pada tahun 2019. Ada tiga sekolah menengah atas yang ditentukan dan dipilih sebagai latar kajian ini, yaitu SMAN 68 Jakarta Pusat, SMAN 41 Jakarta Utara, dan SMAS Perguruan Rakyat 1 Jakarta Selatan. Tiga sekolah tersebut dipilih dan ditentukan atas dasar pertimbangan status, kategori, keterwakilan subwilayah Jakarta, pelaksanaan kegiatan kajian, serta keterbatasan pelaksana kegiatan. Dari ketiga sekolah tersebut, dua sekolah berstatus sekolah negeri dan satu sekolah swasta. Satu sekolah berkategori sekolah unggulan, yaitu SMAN 68 Jakarta Pusat dan dua sekolah merupakan sekolah berkategori nonunggulan, yaitu SMAN 41 Jakarta Utara dan SMAS Perguruan Rakyat 1 Jakarta Selatan. Pemilihan sekolah unggulan dan nonunggulan didasarkan pada asumsi dominasi dan faktor yang memengaruhi terjadinya strategi akomodasi komunikasi, baik dalam bentuk konvergensi maupun divergensi. 
Pengumpulan data dilakukan selama 47 kali pertemuan di tiga sekolah. Proses pengumpulan data dilakukan dengan kelibatan peneliti secara pasif mengikuti kegiatan pembelajaran bahasa Indonesia di kelas. Secara keseluruhan, selama proses pengumpulan data, frekuensi kehadiran peneliti dalam kegiatan pembelajaran bahasa Indonesia di kelas di setiap sekolah berkisar antara sepuluh sampai dua puluh kali pertemuan. Sumber data penelitian ini berupa guru dan siswa dalam kegiatan pembelajaran bahasa Indonesia di kelas pada tiga SMA di Jakarta. Data penelitian ini adalah tuturan verbal dan nonverbal dalam kegiatan pembelajaran bahasa Indonesia. Proses pemerolehan data dilakukan dengan teknik wawancara, observasi, perekaman, dan catatan lapangan.

Teknis analisis data dilakukan secara bertahap, yaitu (1) identifikasi data, mengetahui tuturan-tuturan yang berkonvergensi atau berdivergensi berdasarkan lima strategi komunikasi yang meliputi (a) strategi aproksimasi, (b) interpretabilitas, (c) pengelolaan wacana, (d) pengendalian interpersonal, dan (e) ekspresi emosional (tuturan); (2) klasifikasi data, memberikan deskripsi/keterangan yang bersumber hasil catatan lapangan dan wawancara; dan (3) interpretasi data, menemukan dominasi penggunaan strategi akomodasi komunikasi dalam pembelajaran di kelas. Validasi data dilakukan melalui teknik triangulasi, crosscheck antara keterkaitan teori dan data melalui sudut pandang informan kunci yaitu guru dan antarpeneliti.

\section{PEMBAHASAN}

Berdasarkan hasil analisis data terhadap tiga sekolah di Jakarta, yaitu SMAN 68 Jakarta Pusat, SMAN 41 Jakarta Utara, dan SMAS Perguruan Rakyat I Jakarta Selatan, diperoleh temuan sebagai berikut. Pertama, tiga strategi, yaitu strategi aproksimasi, pengelolaan wacana, dan ekspresi emosional mendominasi akomodasi komunikasi yang digunakan dalam pembelajaran bahasa Indonesia di tiga SMA tersebut. Kedua, wujud akomodasi komunikasi yang terjadi saat pembelajaran di kelas, baik konvergensi maupun divergensi, memengaruhi penggunaan strategi akomodasi komunikasi dalam pembelajaran bahasa Indonesia di kelas. Ketiga, konvergensi dilakukan oleh guru agar siswa memiliki kesiapan mental, kepercayaan diri, dan keberanian menyampaikan pendapat dalam proses belajar, sedangkan divergensi dilakukan oleh guru untuk menunjukkan kekuasaan dan perbedaan peranan dalam percakapan. Selain itu, strategi ini juga memperlihatkan proses hubungan timbal-balik komunikasi yang di dalamnya terkait dengan topik yang dikomunikasikan (materi pembelajaran) sehingga di luar dari topik komunikasi tersebut guru akan memberi batasan atau sekat untuk tidak keluar dari materi pembelajaran yang sedang disampaikan. 


\section{Proses Strategi Akomodasi Komunikasi Guru-Murid dalam Pembelajaran di Kelas}

\section{Strategi Divergensi Pengelolaan Wacana}

Komunikasi dua arah guru dan siswa dalam prosesnya memuat strategi akomodasi komunikasi. Salah satunya adalah strategi discourse management (pengelolaan wacana). Strategi tersebut berkaitan dengan kebutuhan mitra tutur dalam percakapan (isi dan topik). Mitra tutur perlu tahu isi/topik, posisi penutur dan mitra tutur, raut wajah, dan struktur percakapan (kapan giliran bertutur, misalnya guru mendominasi percakapan dalam pembelajaran, maka guru telah berdivergensi, termasuk juga lelucon). Penutur dan mitra tutur yang digambarkan dalam temuan data ini adalah guru dan siswa. Komunikasi guru dan siswa memuat pengelolaan wacana yang bertujuan untuk memastikan tidak keluarnya pembicaraan dari topik.

Suasana atau situasi tuturan dinamis dalam kelas sering membuat guru melakukan strategi divergensi pengelolaan wacana. Tujuannya adalah melakukan kontrol dalam kelas. Perlakuan komunikasi guru kepada siswa berbeda karena jenjang dan jurusan. Struktur jenjang dan jurusan memengaruhi guru dalam menentukan pilihan strategi yang digunakan di dalam kelas seperti yang tergambar dalam kutipan dialog berikut.

\begin{tabular}{|l|l|}
\hline Guru & Bu Astri nanya dulu nih, selain panitia qurban yang ga masuk siapa ? \\
\hline Murid & Ga tahu Bu \\
\hline Murid & Widodo dan teman-temannya.... \\
\hline Guru & Coba liat teman kanan-kirinya ada ga? yang kamu rasa sakit, ada ga yang merasa sakit ? \\
\hline Murid & Dezkia Bu \\
\hline Guru & Dezkia kenapa? \\
\hline Murid & Kurang tahu saya Bu \\
\hline & $\begin{array}{l}\text { Ga ada info ya? baik eeeee..... Ibu rasa kalian sudah paham karakteristik kontrak belajar, } \\
\text { poin pertama adalah kamu jangan menggunakan handphone kecuali Ibu yang menyuruh, } \\
\text { Ibu masih melihat ada beberapa yang masih chating disimpen dulu handphone-nya, ketika } \\
\text { Ibu perintahkan atau instruksikan maka kalian gunakan oke, Ibu mengingatkan lagi nih } \\
\text { yang Namanya kontrak belajar kita yang mau tidak mau kalian harus sepakati, siapa yang } \\
\text { masih ingat? apa kontrak belajar kita? (“Kelas dua siang” tidak terlalu terdengar 0129), satu? }\end{array}$ \\
\hline Murid & \begin{tabular}{l} 
Ga boleh main HP Bu (jawab salah satu siswa) \\
\hline
\end{tabular}
\end{tabular}

Sumber: Data Primer, 2019

Situasi tutur di kelas, saat dalam suasana kurban, ketika guru masuk ke dalam kelas, sangat dinamis. Guru mencoba memverifikasi siswa yang tidak hadir atau tidak ikut pada mata pelajaran bahasa Indonesia. Guru banyak menemukan siswa tidak berada pada tempatnya. Kutipan dialog di atas menunjukkan guru melakukan divergensi sesuai dengan pendekatan yang dijabarkan Giles (2016), yang menyatakan bahwa pembicara terkadang menonjolkan perbedaan verbal dan nonverbal di antara diri mereka sendiri dan orang lain. Guru mencoba mengingatkan siswa akan komitmen yang dibangun bersama sebagai kesepakatan dalam kontrak belajar. Guru tidak mengakomodasi kebutuhan mitra tutur 
yaitu siswa untuk izin keluar kelas dengan alasan sebagai panitia kurban. Gambaran deskripsi tersebut didukung juga oleh tampilan fisik seperti raut wajah saat berkomunikasi yang tampak dari guru saat melakukan penegasan kontrak belajar yaitu menunjukkan ekspresi kecewa. Komunikasi nonverbal guru dilakukan dengan menunjukkan raut wajah kecewa karena ketidakhadiran siswa di mata pelajarannya. Temuan ini sejalan dengan Giles (2016) yang menyatakan bahwa pembicara terkadang menonjolkan perbedaan verbal dan nonverbal di antara diri mereka sendiri dan orang lain yang dalam hal ini ialah guru dan siswa.

\section{Strategi Konvergensi Pengelolaan Wacana}

Strategi pengelolaan wacana (discourse management strategies) mengarah pada strategi ketika penutur fokus pada pembicaraan makro mitra tutur, penutur memiliki kepentingan bersama seperti isi atau topik percakapan, lalu penutur melakukan pengelolaan nonverbal, seperti posisi raut wajah, posisi penutur dan mitra tutur, serta struktur percakapan. Banyaknya interaksi yang dibangun dalam pembelajaran, antara guru-siswa melalui pertanyaan dan umpan balik, mencirikan pengelolaan wacana baik yang bersifat konvergensi maupun divergensi seperti yang tergambar dalam contoh kutipan data berikut.

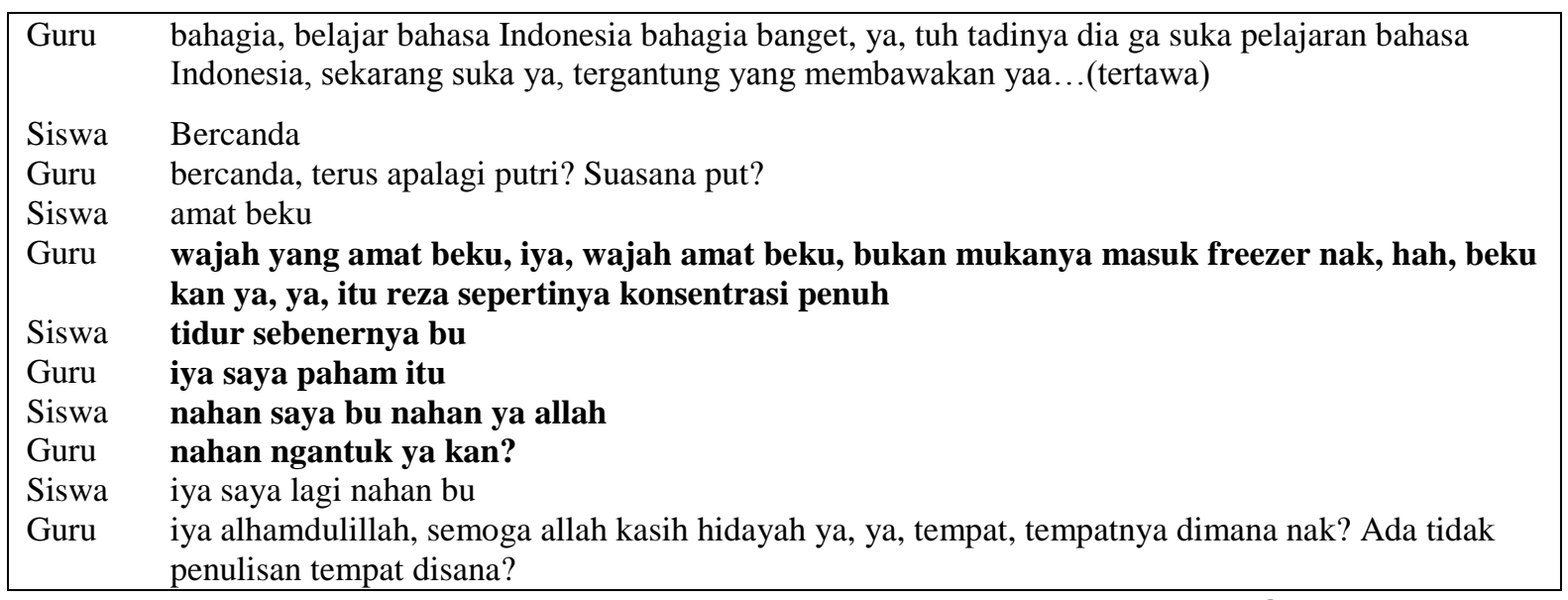

Situasi tuturan yang terjadi dalam contoh kutipan data di atas terjadi saat guru mencoba melakukaan penyegaran suasana kegiatan pembelajaran dengan memberikan respons terhadap pernyataan siswa yang terlihat tidak memiliki minat terhadap pembelajaran bahasa Indonesia. Dominasi tuturan guru dan siswa dalam interaksi bersemuka tersebut memunculkan adanya strategi konvergensi pengelolaan wacana yang dilakukan oleh guru (penutur). 


\section{Penguatan Strategi Divergensi}

Proses interaksi antara guru dan siswa tetap berlangsung selama pembelajaran. Guru tetap menunjukkan strategi komunikasi divergensi karena guru menonjolkan perbedaan verbal dan nonverbal dengan siswa. Hal tersebut dapat dilihat pada contoh kutipan berikut.

\begin{tabular}{|c|c|}
\hline Guru & Tidak boleh main HP, terus yang kedua? \\
\hline Murid & Ga boleh makan (jawab salah satu siswi) \\
\hline Guru & Tidak boleh makan, minum boleh, tiga? \\
\hline Murid & Aktif Bu aktif (jawab salah satu siswa) \\
\hline Guru & Aktif pasti karena Ibu selalu menilai-nilai keaktifan kelas setiap hari, empat? \\
\hline Murid & Ga boleh pasif Bu (jawab salah satu siswa) (diselingi tertawaan siswa/siswi lainnya) \\
\hline Guru & Iya, itu salah satu keaktifan, \\
\hline Murid & Nih ga ada akhlaknya $\mathrm{Bu}$ (salah satu siswa bercanda sambil diiringi tertawaan teman-temannya) \\
\hline & Oke yang keempaaaaat tidak boleh ke toilet di jam pertama, kalau sudah masuk ke jam \\
\hline Guru & $\begin{array}{l}\text { kedua Ibu persilahkan, karena kenapa? di jam pertama itu kalian sudah harus siap sedia jadi } \\
\text { pembelajaran kondusif, kecuali dalam keadaan darurat. Yang keima tugas tidak boleh? }\end{array}$ \\
\hline
\end{tabular}

Sumber: Data Primer, 2019

Berdasarkan temuan data dan hasil analisis, komunikasi akomodasi yang diperlihatkan oleh guru ke siswa masuk pada strategi discourse management (pengelolaan wacana). Guru berulang kali melakukan penegasan kontrak belajar kepada siswa. Guru tidak berkonvergensi kepada siswa untuk ikut dalam candaan mereka. Guru tetap tegas pada aturan kontrak belajar yang telah disepakati. Topik dan konteks komunikasi guru menerangkan bahwa ada kesepakatan dalam kontrak belajar yang mengikat dan mengatur prilaku siswa untuk taat pada aturan. Guru melakukan pengelolaan wacana aturan berperilaku siswa dalam proses pembelajaran bahasa Indonesia. Saat proses pembelajaran berlangsung, komunikasi guru tetap divergensi. Pada siswa yang terlibat dalam percakapan dengan guru, pola komunikasinya berkonvergensi ke topik pembicaraan guru. Proses interaksi antara penutur dan mitra tutur menunjukkan bahwa komunikasi timbal-balik memberikan adanya pertukaran nilai yang dalam hal ini ialah pengelolaan wacana aturan kesepakatan kontrak belajar.

Penguatan strategi divergensi juga tampak pada saat guru memberi batas atau ruang terhadap pengelolaan wacana pada lingkup pembicaraan untuk kepentingan bersama yang dalam hal ini ialah tujuan pembelajaran yang ingin dicapai. Hal tersebut terdeskripsikan dalam contoh kutipan dialog di bawah ini.

\begin{tabular}{|ll|}
\hline Guru & Sudah waktunya belajar, tidak ada yang makan! \\
Siswa & Lapar, Bu. \\
Guru & Udah, jangan main hp! (gemuruh suara siswa) \\
& Yah dengarkan, udah, oke, lanjutnyaa, sttt, udah, makannya sudah, oke tadi teks ekplanasi \\
& adalah peristiwa atau fenomena alam, sosial, budaya, ekonomi, dan lain-lain. Sebenarnya ada \\
& banyak, ini hanya bagiannya saja, lalu di teks ekplanasi ada sebuah latar belakang, ada apa lagi? \\
Siswa & Fakta. \\
Guru & Selain fakta, ada apa lagi? \\
Siswa & Sebab akibat. \\
\hline
\end{tabular}




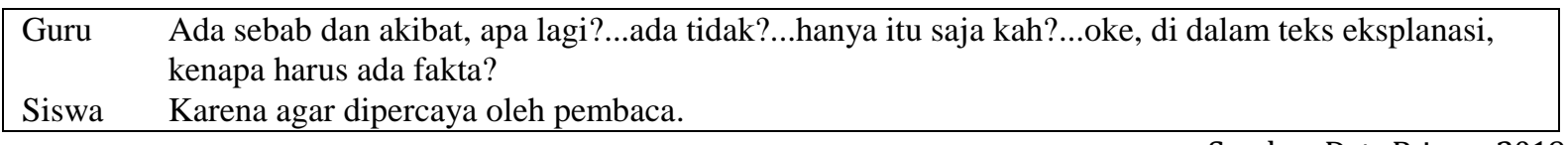

Kutipan tuturan interaksi guru dan siswa di atas terjadi saat kegiatan pembelajaran kembali dimulai setelah terjeda oleh istirahat. Guru sebagai penutur kembali mengajak mitra tuturnya (siswa) untuk melanjutkan kembali kegiatan pembelajaran. Ekspresi tuturan "sttt" menyuratkan perbedaan status guru secara verbal untuk tidak menoleransi siswa untuk makan dan bermain hp saat kegiatan pembelajaran sudah dimulai. Hal tersebut juga diperkuat tuturan guru yang menfokuskan pada hubungan interpersonal antara guru dan siswa terhadap ketentuan kegiatan belajar yang disepakati.

\section{Strategi Konvergensi Emotional Expression (Tuturan Emosional)}

Giles (2016) berpendapat bahwa strategi akomodasi emotional expression adalah ketika penutur khawatir tentang perasaan orang lain, penutur dapat menggunakan emosi ekspresi untuk memberikan kenyamanan terhadap kekhawatiran individu. Proses akomodasi tuturan merupakan interaksi bahasa berkonvergensi dengan mitra wicaranya, ketika penutur dapat menempatkan diri dan merasakan emosional mitra wicaranya maka akan terkondisikan komunikasi yang nyaman dan cair (Kurniawati, 2019). Komunikasi yang menggunakan pendekatan ini sangat dekat dengan upaya cepat beradaptasi dengan lingkungan sosial. Penerimaan lingkungan sosial sangat dipengaruhi dengan strategi komunikasi individu sebagai upaya untuk mempercepat proses adaptasi sosial individu dengan lingkungan sosial yang variatif. Friksi dan kegaduhan sosial seringkali muncul karena adanya disfungsi komunikasi akomodasi-individu cenderung tidak memperhatikan strategi konvergensi akomodasi komunikasi yang tepat.

Jika dikaitkan dengan temuan data hasil dari analisis, kelas menjadi ruang lingkungan sosial kecil atau gambaran corak prilaku masyarakat mini sebab komposisi dan strukur latar belakang sosial siswa yang majemuk. Variasi latar belakang sosial siswa tidak hanya pada tataran etnis, suku, dan bahasa, tetapi juga kelas ekonomi dan latar belakang keluarga. Kedua hal tersebut, kelas ekonomi dan latarbelakang keluarga, menjadi suplemen tambahan yang dapat memengaruhi pola komunikasi yang tercipta dalam kelas.

Guru sebagai mediator dan fasilitator komunikasi tidak hanya berinteraksi tatap wajah dengan satu individu, tetapi tiga puluh wajah dengan latar belakang sosial yang bervariasi. Guru memiliki strategi komunikasi yang variatif tergantung pada kondisi dan jenis kelas apa yang akan diajar. Gambaran ini jelas ada pada jenjang kelas X dan XI jurusan IPA dan IPS. Guru memiliki cara yang berbeda dalam menghadapi kelas dengan jenjang dan jurusan yang berbeda. Di SMA Negeri 68 Jakarta sebagai tempat 
objek pengambilan data, guru mata pelajaran Bahasa Indonesia memiliki tugas pengajaran pada kelas X IPA, X IPS, dan XI IPA. Selama observasi, guru menunjukkan cara berkomunikasi yang berbeda ketika menghadapi kelas IPA dan IPS seperti yang dapat dilihat pada gambar 1 berikut.

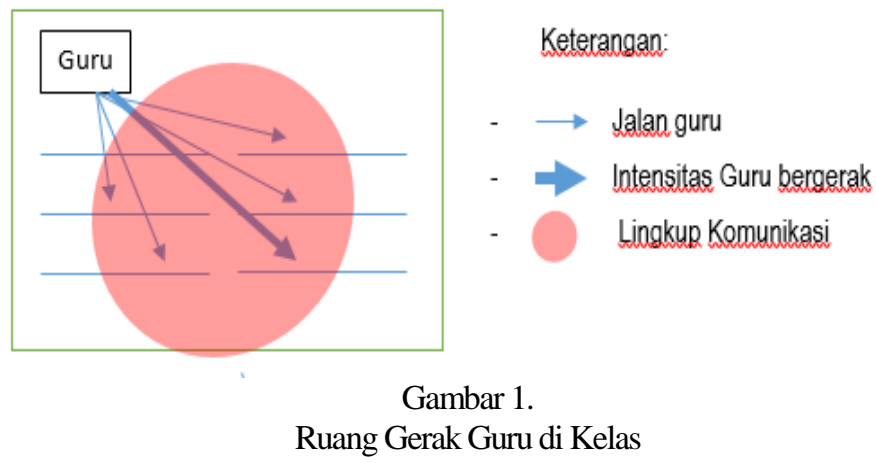

Gerak guru pada mata pelajaran Bahasa Indonesia di kelas XI IPA 3 menunjukkan bahwa guru menguasai lingkup komunikasi di kelas tersebut. Akomodasi komunikasi yang ditunjukkan guru lebih menggunakan strategi emotional expression. Strategi komunikasi ini tidak digunakan pada moment interaksi kolektif, tetapi digunakan ketika moment interaksi interpersonal. Garis panah yang ditebalkan menggambarkan bahwa guru pada proses belajar berulang-ulang mendatangi salah satu siswa yang duduk pada baris belakang. Pendekatan interpersonal yang dilakukan guru kepada individu siswa bertujuan untuk membangkitkan motivasi belajar karena siswa tersebut merupakan siswa yang perlu didekati dan diberikan perhatian lebih ketika proses belajar. Siswa tersebut adalah salah satu siswa yang masuk kategori tidak dapat diluluskan dan dinaikkan kelas karena prestasi akademik cenderung terus menurun dan tidak ada perubahan positif. Berkat pendekatan intensif dengan menggunakan komunikasi strategi emotional expression, guru mampu membangkitkan rasa kepercayaan diri siswa tersebut. Berdasarkan penuturan guru tersebut, siswa menunjukkan perubahan, mulai dari keinginan untuk selalu bertanya, dapat memberikan argumentasi ketika belajar, responsif dengan tugas, dan tidak menunjukkan gejala malas belajar (tidur di kelas). Perubahan siswa tersebut sesuai dengan pengamatan peneliti di kelas, yaitu guru memiliki intensitas lebih dalam tatap wajah dan komunikasi dengan siswa tersebut. Hal itu juga diperkuat dengan hasil potongan dialog yang dilakukan oleh guru dan siswa tersebut.

\begin{tabular}{|ll|}
\hline Siswa & Ibu, apakah berita ini bisa masuk? \\
Guru & Harus fakta ya Nak... jangan opini ya.....di rumah banyak baca yaa...(guru tetap memberikan motivasi \\
& kepada anak didiknya), lebih usaha keras lagi ya nak, nanti ibu akan bantu jika ada kesulitan. Kamu bagus \\
& sudah menunjukkan perubahan, tetap pertahankan, semangat ya nak...jadi berita itu harus menggambarkan \\
& fenomena sosial....jangan sampai tentang jenazah terbakar, hahahha, jangan laman gosip......coba cari referensi \\
& di internet...... \\
Siswa & Baik Ibu, terima kasih, saya akan mencoba mencari referensi lainnya.... \\
\hline
\end{tabular}

Sumber: Data Primer, 2019

Selain itu, guru juga menyampaikan komunikasi yang menunjukkan rasa respect kepada siswa sebagai mitra tutur. Hakikatnya setiap individu memiliki keinginan harfiah untuk dihargai dan diakui 
eksistensinya melalui pujian. Maka dari itu, untuk mencapai komunikasi yang efektif antara penutur dan mitra tutur, pujian perlu diberikan kepada mitra tutur seperti temuan data dari dialog di atas, yaitu guru menyampaikan rasa respect kepada siswa dengan menyampaikan pujian "Semangat ya Nak". Ujaran seperti itu dapat memberikan kesan mitra tutur dihargai dan diakui eksistensinya dalam percakapan dialogis antara guru dan siswa. Dialog di atas juga memberikan efek jangka panjang yang luar biasa. Hal itu terjadi karena memuji tidak saja bisa membuat prestasi siswa meningkat, tetapi juga-poin utamanya - bisa menjadikan guru sebagai sosok yang sangat dikagumi dan dipercaya. Semakin sering guru melakukan pujian kepada siswa akan semakin mudah guru mengendalikan siswa. Inilah letak kunci utama strategi konvergensi emotional expression.

\section{Alasan atau Faktor Penggunaan Strategi Akomodasi di Kelas}

\section{Konvergensi}

Palomares, Giles, Soliz, dan Gallois (2016) mendefinisikan konvergensi sebagai strategi adaptasi individu terhadap perilaku komunikatif satu sama lain. Orang akan beradaptasi terhadap kecepatan bicara, jeda, senyuman, tatapan mata, dan perilaku verbal dan nonverbal lainnya. Dalam komunikasi dua arah (Giles dalam Dhanawaty, (2002:2)), khususnya komunikasi bersemuka, pewicara umumnya berusaha menyesuaikan diri ke arah mitra wicara baik secara verbal maupun nonverbal. Penyesuaian diri secara verbal dilakukan oleh pewicara dengan jalan memodifikasi tuturan sehingga menjadi lebih mirip dengan tuturan yang dipakai oleh mitra wicara. Akan tetapi, dalam peristiwa atau situasi tuturan tertentu dapat juga terjadi proses sebaliknya yaitu pewicara memodifikasi tuturan sehingga menjadi semakin tidak mirip dengan tuturan wicarannya. Hal tersebut dapat tergambarkan berdasarkan temuan data di lapangan, seperti ketika guru sebelum memulai pelajaran, seringkali ia menyisipkan sapaan dengan kata "sayang" kepada siswa untuk mencairkan suasana tegang selepas belajar mata pelajaran sebelumnya atau pada jam kritis di siang hari. Hal tersebut dapat tergambar pada kutipan berikut.

\begin{tabular}{|ll|}
\hline Guru & Pengulangan ucapan (apa sayang, apa nak)? Guru merespons tanggapan dari siswa. \\
Siswa & Apakah paragraf 2 tentang kebenaran menurut penulis, demonstrasi tidak sepakat bahwa demo adalah \\
& penyebab kerusakan? Apakah ini termasuk sebagai pengenalan fenomena? \\
Guru & Bagaimana, Nak, struktur teks eksplanasi? \\
Siswa & (berbarengan) Adanya penegasan ulang, ulasan paragraf dalam teks eksplanasi. \\
Guru & "Reaksi Ibu guru Astriana terlihat tersenyum ketika ada siswa salah dalam menyampaikan \\
& jawaban" $\rightarrow$ Kondisi pengamatan observer ke guru. Luar biasa, kalian sudah bisa \\
& menyampaikan ide $\rightarrow$ Guru tidak langsung menyalahkan jawaban argumentasi siswa. \\
\hline
\end{tabular}

Sumber: Data Primer, 2019

Strategi akomodasi konvergensi yang dilakukan oleh guru bertujuan untuk membuat siswa memiliki kesiapan mental dan kepercayaan diri dan berani menyampaikan pendapat dalam proses belajar. 
Strategi komunikasi menjadi faktor perantara untuk meningkatkan minat belajar siswa. Dalam komunikasi dialog, dua individu akan menunjukkan pengaruh dan dipengaruhi. Penutur dan mitra tutur pada hakikatnya ingin dihargai dan diakui eksistensinya. Jika penutur ingin mengendalikan pengaruh kepada mitra tutur, berikanlah respons antusias dan pujian kepada mitra tutur. Hal ini dilakukan agar tidak ada kesan jarak dalam berkomunikasi. Komunikasi konvergensi merupakan cara ampuh untuk dapat mengendalikan pengaruh penutur kepada mitra tutur, seperti guru yang mampu mengendalikan siswa.

Transformasi komunikasi dua arah antara penutur dan mitra tutur menunjukkan gejala konvergensi yang ditunjukkan dengan individu dapat beradaptasi terhadap prilaku komunikasi satu sama lainnya. Senyum dan tatapan mata tertarik pada topik pembicaraan menjadi tanda "morse" komunikasi nonverbal yang dapat membuat mitra tutur merasa dihargai (mendapat respect) dan diakui eksistensinya.. Guru dalam hal ini harus memahami strategi komunikasi konvergensi. Dinamika kelas yang majemuk tentunya tidak menjadi patokan bahwa konvergensi adalah satu-satunya strategi komunikasi yang ampuh. Ada saatnya guru memainkan dua tipe akomodasi komunikasi sekaligus (konvergensi dan divergensi). Kondisi itu tergantung pada situasi kelas dan karakter siswa.

\section{Divergensi}

Giles (2016) menyatakan bahwa pembicara terkadang menonjolkan perbedaan verbal dan nonverbal di antara diri mereka sendiri dan orang lain. Divergensi adalah ketika tidak terdapat usaha untuk menunjukkan persamaan di antara para pembicara. Dua orang berbicara satu sama lain tanpa adanya kekhawatiran untuk mengakomodasi satu sama lain. Divergensi tidak boleh disalahartikan sebagai suatu cara untuk tidak sepakat atau tidak memberikan respons pada komunikator yang lain. Divergensi tidak sama dengan ketidakpedulian. Ketika orang melakukan divergensi, mereka memutuskan untuk mendisosiasikan diri mereka dari komunikator dan percakapan tersebut. Alasan-alasan untuk divergensi dapat bervariasi. Divergensi merupakan satu cara bagi para anggota komunitas budaya yang berbeda untuk mempertahankan identitas sosial.

Orang melakukan divergensi berkaitan dengan kekuasaan dan perbedaan peranan dalam percakapan. Divergensi seringkali terjadi dalam percakapan ketika terdapat perbedaan kekuasaan di antara para komunikator dan ketika terdapat perbedaan peranan yang jelas dalam percakapan (dokter-pasien, orang tua-anak, pewawancara-terwawancara, dst). Dragojevic dkk (2016) menyatakan bahwa para interaktan yang memiliki status lebih tinggi mungkin akan berbicara dalam jangka waktu yang lebih lama, memulai hampir semua topik pembicaraan, berbicara lebih pelahan, dan mempertahankan postur tubuh yang lebih santai dibandingkan yang kurang berkuasa. Divergensi terjadi karena seseorang ingin menunjukkan bahwa yang lainnya kurang berkuasa. 
Pengelolaan komunikasi antara guru dan siswa dimanifestasikan dalam bentuk interaksi kolektif di dalam kelas. Normatifnya, komunikasi dialog dua arah muncul ketika guru dan siswa berdiskusi dalam belajar. Guru dapat mengelola strategi komunikasi dalam bentuk konvergensi dan divergensi. Keseimbangan dua strategi ini menjadi kekuatan seni berkomunikasi antara guru dan siswa. Guru memainkan peran penting dalam pengelolaan komunikasi. Pengelolaan komunikasi yang dilakukan secara berlebih antara guru atau siswa akan mengakibatkan adanya dominasi yang tendensinya dapat bertentangan dengan adab komunikasi. Antara jurusan IPA dan IPS pada pelajaran Bahasa Indonesia di kelas X, XI, dan XII, guru Bahasa Indonesia memiliki perbedaan strategi komunikasi kepada siswa. Hal tersebut bergantung pada situasi kelas.

Pada tataran kelas X, XI, dan XII kelas IPS guru akan cenderung konvergensi dalam akomodasi komunikasi. Hal ini dilakukan karena perlunya pendekatan emosional yang dilakukan oleh guru pada kelas IPS. Kelas jurusan IPS cenderung dinamis dan sekat-sekat ilmiah cenderung longgar. Guru seakan dapat masuk dalam dunia siswa dan memahami cara pandang siswa. Kelas ini juga cenderung tidak kaku. Guru mengajar dengan cara berdiskusi dan mengonstruksi wacana ilmiah bersama siswa. Siswa diajak secara persuasif untuk memahami konteks materi belajar dari berbagai sudut pandang. Dalam proses tersebut, terjadi proses negosiasi antara guru dan siswa, tidak ada jarak sosial, dan cenderung menggunakan gaya bahasa yang longgar (bahasa gaul). Guru ada kecenderungan toleran dengan narasi berpikir siswa yang "liar" membahas hal di luar konteks pelajaran seperti curhat dan bercanda.

Pada situasi tertentu, guru bahasa Indonesia pada jenjang dan jurusan kelas yang sama dapat mengubah strategi komunikasinya dari konvergensi ke divergensi. Pengubahan ini disebabkan adanya proses komunikasi konvergensi yang berlebih yang terjadi antara siswa dan guru. Semufakat dengan pandangan Natalia (2018) konvergensi berlebihan masuk dalam akomodasi berlebihan. Tanda yang disematkan kepada penutur (siswa) yang dianggap terlalu berlebihan menyebabkan pendengar (guru) mempersepsikan diri mereka tidak setara. Terdapat banyak dampak serius dari akomodasi berlebihan, termasuk menghindari percakapan dan mengonstruksi sikap negatif terhadap pembicara. Akomodasi berlebihan dapat menjadi hambatan untuk mencapai keterpahaman makna dalam sebuah interaksi. Sebagaimana temuan dalam penelitian ini yang memaparkan bahwa konvergensi biasanya memangkas jarak status sosial guru dan siswa, pemangkasan jarak inilah—jika berlebihan — dapat menyebabkan guru menegasikan statusnya sebagai guru. Apabila pandangan Giles (2016) ditelisik secara teoritik, divergensi lebih dimaknai sebagai usaha untuk menonjolkan perbedaan diri antara penutur dan mitra tutur baik verbal maupun nonverbal, serta lebih untuk mempertahankan identitas sosial ataupun budaya. Namun, hal ini bukan berarti bahwa divergensi menunjukkan tidak tercapainya konsensus antara penutur dan mitra tutur. Bisa jadi, itu merupakan penegasan status yang melekat pada penutur dan mitra tutur. Hal ini dapat terjadi 
dalam proses pembelajaran antara guru dan siswa. Guru yang melakukan divergensi kepada siswa bertujuan untuk mengendalikan situasi kolektif dalam komunikasi karena tokoh sentral guru sebagai penutur menghadapi variasi individu mitra tutur.

Divergensi guru dilakukan untuk pengelolaan dan pengendalian prilaku siswa. Guru akan menunjukkan identitasnya sebagai guru yang harus dihormati, dipatuhi, dan dijadikan seperti orang tua siswa sendiri. Hal ini terjadi ketika cara komunikasi siswa di luar batas kewajaran, seperti ribut di kelas, berbicara di luar konteks yang ditoleransi, dan perilaku siswa yang menunjukkan rasa tidak hormat kepada guru. Hal tersebut dapat dilihat pada temuan data dari dialog antara guru dan siswa berikut.

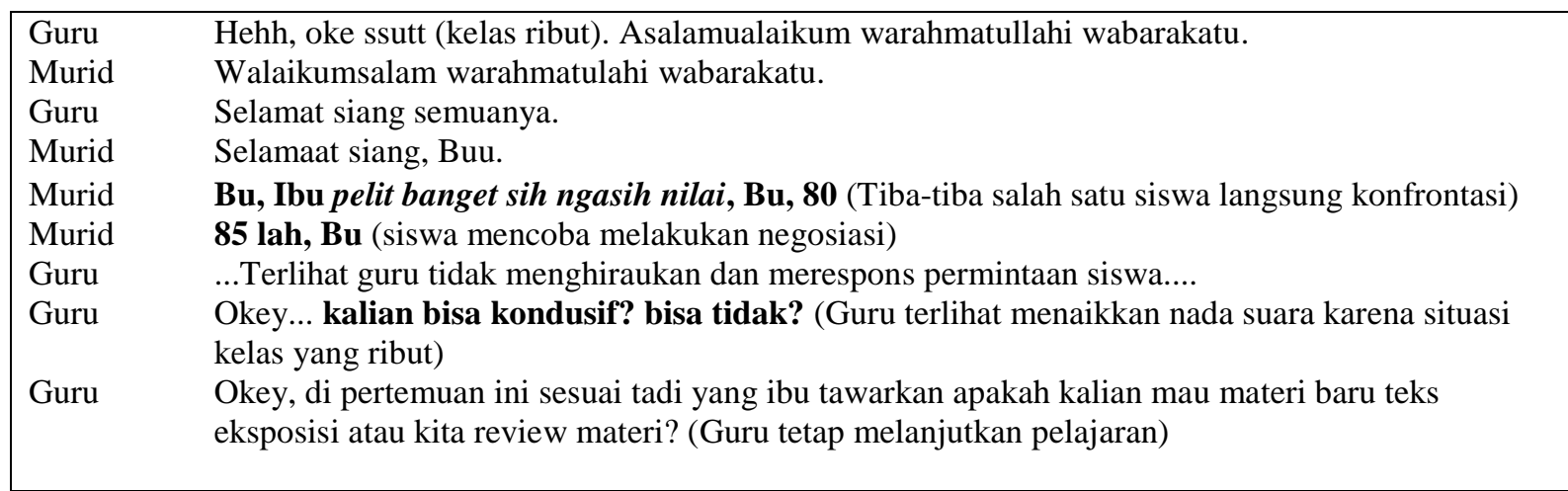

Sumber: Data Primer, 2019

Faktor pendorong terjadinya akomodasi komunikasi di kelas ialah konvergensi dan divergensi. Kedua hal ini menjadi faktor pendorong terjadinya akomodasi dengan berbagai strategi komunikasi. Akomodasi komunikasi pada temuan peneliti, sebagai upaya yang dilakukan oleh penutur dan mitra tutur dalam hal ini guru dan siswa dalam adaptasi, berupa nada suara, topik pembicaraan, gerak tubuh, bahasa nonverbal, dan pendekatan personal. Guru dan siswa dalam proses pembelajaran dibatasi jarak sosial berupa status. Akomodasi komunikasi guru-siswa dalam proses pembelajaran di kelas memainkan setiap strategi komunikasi yang berbeda. Pendekatan yang digunakan guru berbeda di setiap jenjang dan jurusan. Guru akan menghadapi cara komunikasi antara anak kelas X, XI, dan XII serta jurusan IPA dan IPS dengan berbeda. Hal ini dimaksudkan agar tujuan pembelajaran dapat tercapai dan tersampaikan. Pengelolaan komunikasi yang dilakukan guru bahasa Indonesia dalam temuan peneliti menunjukkan suatu realitas adil dalam mendidik (Equality in education). Guru memandang semua siswa sama tanpa ada label; guru memiliki kedekatan emosional dengan siswa, khususnya siswa yang masuk kategori marginal dalam proses belajar; guru memberikan perhatian lebih dengan upaya komunikasi intens yang bertujuan untuk membangkitkan dan mendorong kepercayaan diri siswa untuk belajar. Keseimbangan strategi konvergensi emotional expression dan divergensi discourse management menjadi senjata ampuh dalam mengurangi friksi-friksi komunikasi antara guru dan siswa. Selain itu, kedua strategi tersebut dalam akomodasi komunikasi menunjukkan pengelolaan kelas yang baik. 


\section{PENUTUP}

Hasil temuan dan analisis menunjukkan bahwa guru memainkan peran penting dalam penggunaan strategi komunikasi. Jika ditelisik dari perspektif strategi komunikasi akomodasi yang dikemukakan oleh Giles, dari lima strategi, secara holistik guru Bahasa Indonesia dominan menggunakan tiga strategi, yaitu strategi aproksimasi (approximation), strategi pengelolaan wacana (discourse management), dan strategi ekspresi emosional (emotional expression). Ketiga strategi ini cenderung berimbang karena dipengaruhi konteks dan situasi tuturan ketika interaksi guru dan siswa terjadi di kelas. Strategi emotional expression digunakan oleh guru untuk melakukan pendekatan komunikasi kepada siswa yang secara akademik dianggap termarginalkan dalam kompetisi nilai.

Pendekatan ini menunjukkan bahwa pertama, guru cenderung mengakomodasi minat belajar siswa; kedua, keterampilan komunikasi verbal menjadi kunci utama guru dalam membangun suasana belajar di kelas; dan ketiga, guru tidak hanya menjadi konduktor ilmu, tetapi juga percontohan figur ahlak budi pekerti. Seni komunikasi juga tidak hanya sebatas pada pusaran bagaimana guru mampu membuat candaan di kelas, tetapi juga guru mampu memberikan makna dari setiap tuturannya. Akomodasi komunikasi sebaiknya tidak lagi berasaskan label latar belakang sosial siswa. Utamakan advokasi intensif dan persuasif kepada siswa yang memiliki kekurangan kapasitas akademik. Oleh karena itu, pengaruh strategi akomodasi komunikasi berperan penting dalam proses pembelajaran, yaitu sebagai seni kecakapan berkomunikasi.

Semufakat dengan ahli psikologi, setiap siswa memiliki potensi untuk berkembang dan belajar menjadi sosok individu yang berhasil dalam kehidupan sosial. Hal ini sudah menjadi "titah" dan "kodrat" tugas guru yaitu untuk dapat menggali dan menemukan suatu bakat terpendam, terutama pada siswa yang kurang percaya diri dan merasa inferior. Guru yang baik dan bijak harus mampu mengidentifikasi kekurangan setiap siswanya dan menggali potensi bakat kelebihannya. Guru harus mampu membuka akses kesempatan seluas-luasnya bagi siswa dengan kelebihan dan kekurangannya masing-masing.

\section{DAFTAR PUSTAKA}

Crystal, david. (2008). A Dictionary of Linguistics and Phonetics: sixth edition (sixth edit). Blackwell Publishing.

Dhanawaty, N. M. (2002). Teori akomodasi dalam penelitian dialektologi. Makalah Yang Disajikan Dalam Kongres Linguistik Nasional X. Kerja Sama Antara Masyarakat Linguistik Indonesia, Pusat Bahasa, dan Fakultas Sastra Universitas Udayana. 
Dragojevic, M., Gasiorek, \& Giles, H. (2016). Accommodative Strategies as Core of the Theory. In H. Giles (Ed.), Communication Accommodation Theory: Negotiating Personal Relationships and Social Identities across Contexts (pp. 36-59). Cambridge University Press. https://doi.org/10.1017/CBO9781316226537.003

Fiske, J. (2012). Pengantar Ilmu Komunikasi. Rajawali.

Giles, Howard, M. (2016). Accomodation Strategies as Core of the Theory. In H. Giles (Ed.), Coomunication Accomodation Theory (p. 37). Cambridge University Press.

Giles, H. (2016). Communication Accomodation Theory Negotiating Personal Relationships and Social Identities Across Contexts (H. Giles (ed.)). Cambridge University Press. https://doi.org/10.1017/CBO9781316226537

Halliday, M. A. K., \& Hasan, R. (1985). Language, text and context: Aspects of language in a socialsemiotic perspective. Victoria: Deakin University Press.

Indrariani, E. A. (2011). Strategi Komunikasi Mahasiswa Asing dalam Interaksi dan Pembelajaran Bahasa Indonesia (Studi Kasus Mahasiswa Program Darmasiswa Undip Tahun 2010/2011). PAROLE: Journal of Linguistics and Education, 2(1 April), 77-82.

Jones, E., Gallois, C., Callan, V., \& Barker, M. (1999). Strategies of accommodation: Development of a coding system for conversational interaction. Journal of Language and Social Psychology, 18(2), 123-151. https://doi.org/10.1177/0261927X99018002001

Kholidah, U. (2015). Pemertahanan Bahasa Jawa Pada Interaksi Siswa dan Guru dalam Pembelajaran Kajian Sosiolinguistik di Mts Al-Hikmah Pasir Demak. Ranah: Jurnal Kajian Bahasa, 4(2), 105114. https://doi.org/https://doi.org/10.26499/rnh.v4i2.27

Kurniawati, W. (2019). Akomodasi Bahasa di Napan, Nusa Tenggara Timur, Wilayah Perbatasan Indonesia-Timor Leste. Ranah: Jurnal Kajian Bahasa, 8(2), 189. https://doi.org/10.26499/rnh.v8i2.1119

Mahadhir, M., Nor, N. F. M., \& Azman, H. (2014). Communication Accommodation Strategies in Malaysian Multiracial Family Interactions. Procedia - Social and Behavioral Sciences, 118, 259264. https://doi.org/10.1016/j.sbspro.2014.02.035

Natalia, E. C. (2018). Pemilihan Penggunaan Bahasa dalam Interaksi Sebagai Bentuk Adaptasi Antarbudaya di Indonesia. Jurnal Komunikasi Indonesia, 4(2). https://doi.org/10.7454/jki.v4i2.8883

O’MALlEY, J. M., Chamot, A. U., Stewner- Manzanares, G., Russo, R. P., \& Küpper, L. (1985). Learning strategy applications with students of English as a second language. TESOL Quarterly, 19(3), 557-584. https://doi.org/10.2307/3586278

Palomares, N. A., Giles, H., Soliz, J., \& Gallois, C. (2016). Intergroup Accomodation, Social Categories, and Identities. In H. Giles (Ed.), Communication Accommodation Theory: Negotiating Personal Relationships and Social Identities across Contexts (pp. 123-151). Cambridge University Press. https://doi.org/10.1017/CBO9781316226537.007

Purwiyanti, Y., Suwandi, S., \& Andayani, N. (2017). Strategi Komunikasi Pemelajar Bahasa Indonesia bagi Penutur Asing Asal Filipina. Ranah: Jurnal Kajian Bahasa, 6(2), 160. https://doi.org/10.26499/rnh.v6i2.448

Rahman, A. (2015). Strategi Komunikasi dalam Pembelajaran Bahasa Inggris (Penelitian Etnografi Pada Sekolah Internasioanal Aischo Bsd City). BAHTERA : Jurnal Pendidikan Bahasa Dan Sastra, 14(2). 142-155. https://doi.org/10.21009/BAHTERA.142.04

Siddik Masrur; Arifin, Syawal, M. Y. (2019). Strategi Komunikasi Siswa dan Guru Kelas XI SMAN 2 Sangatta Utara dalam Proses Pembelajaran Bahasa Indonesia. Diglosia: Jurnal Kajian Bahasa, Sastra, Dan Pengajarannya, Vol 2 No 1 (2019): DIGLOSIA, Edisi Februari 2019, 15-38. https://doi.org/10.30872/diglosia.v2i1.15

Toenlioe, A. J. (2016). Sosiologi Pendidikan (Ketiga). PT Refika Aditama. 